UDC 629.8

Doi: $10.31772 / 2587-6066-2019-20-1-42-53$

For citation: Birukov V. I., Nazarov V. P., Kurguzov A. V. [Estimation of the efficiency of spacecraft transportation with minimal radiation degradation of solar cells]. Siberian Journal of Science and Technology. 2019, Vol. 20, No. 1, P. 42-53. Doi: 10.31772/2587-6066-2019-20-1-42-53

Для цитирования: Бирюков В. И., Назаров В. П., Кургузов А. В. Оценка эффективности транспортировки космических аппаратов с минимальной радиационной деградацией солнечных фотоэлементов // Сибирский журнал науки и технологий. 2019. Т. 20, № 1. С. 42-53. Doi: 10.31772/2587-6066-2019-20-1-42-53

\title{
ESTIMATION OF THE EFFICIENCY OF SPACECRAFT TRANSPORTATION WITH MINIMAL RADIATION DEGRADATION OF SOLAR CELLS
}

\author{
V. I. Birukov ${ }^{1}$, V. P. Nazarov ${ }^{* 2}$, A. V. Kurguzov ${ }^{1}$ \\ ${ }^{1}$ Moscow Aviation Institute (National Research University) \\ 4, Volokolamskoe highway, A-80, GSP-3, 125993, Moscow, Russian Federation \\ ${ }^{2}$ Reshetnev Siberian State University of Science and Technology \\ 31, Krasnoyarsky Rabochy Av., Krasnoyarsk, 660037, Russian Federation \\ *E-mail: nazarov@sibsau.ru
}

\begin{abstract}
Transport operations that ensure the change of the orbit of a spacecraft or its transfer to the departure trajectory are an integral part of almost all space missions. Increasing requirements for the efficiency of transporting spacecraft form the need to search for possible ways to increase this efficiency and assess the characteristics associated with the proposed methods.

Current boosters and interorbital tugs, as a rule, use a chemically powered cruise engine, although solutions with the use of an electric jet engine are becoming more common. Due to the high rate of the outflow of working fluid which is much higher than that of combustion products in a chemical engine, the efficiency of use of the substance mass by an electric jet engine significantly exceeds this indicator for a chemical engine. However, the low thrust provided by the electric jet engine leads to high duration of the transport operation and, as a result, to considerable time of exposure to the outer space factors, in particular, radiation. Therefore, the use of the electric jet engine only does not always meet the requirements for the mission.

One of the promising ways to increase the efficiency of transport operations is the combination of the traditional chemical and electric jet engines in the propulsion system. Various aspects of the use of such an integrated propulsion system (IPS) consisting of a solar electric jet system and "Fregat" booster were considered, for example, in the framework of "Dvina TM" research project.

Unlike a chemical engine, in which energy is released from chemical bonds, the energy for accelerating the working fluid by an electric jet engine is supplied from outside. Solar batteries are the most widespread energy source in nearearth orbits, where the amount of solar radiation is sufficient to meet the energy needs of a spacecraft. Solar batteries are sensitive to radiation, damage accumulates in their internal structure and their characteristics degrade. Therefore, there is a need to account for the radiation dose accumulated during the execution of the transport operation and to evaluate the reduction in the efficiency of solar batteries. Uneven irradiation intensity in the radiation belts formed by the Earth's magnetic field (Van Allen belts) can be taken into account if the assessment of the radiation intensity at the trajectory points of the maneuver is made using the Earth radiation belt model.

The paper proposes a method that allows taking into account the effect of ionizing radiation on the degradation of solar batteries when performing a transport operation using an integrated propulsion system based on a liquidpropellant rocket engine and an electric jet engine, taking into account the chosen trajectory and the model of the Earth's radiation belt.
\end{abstract}

Keywords: integrated propulsion system, electric jet engine, Van-Allen radiation belt, solar battery, degradation.

\section{ОЦЕНКА ЭФФЕКТИВНОСТИ ТРАНСПОРТИРОВКИ КОСМИЧЕСКИХ АППАРАТОВ С МИНИМАЛЬНОЙ РАДИАЦИОННОЙ ДЕГРАДАЦИЕЙ СОЛНЕЧНЫХ ФОТОЭЛЕМЕНТОВ}

\author{
В. И. Бирюков ${ }^{1}$, В. П. Назаров ${ }^{* 2}$, А. В. Кургузов ${ }^{1}$
}

\footnotetext{
${ }^{1}$ Московский авиационный институт (национальный исследовательский университет) Российская Федерация, 125993, г. Москва, А-80, ГСП-3, Волоколамское шоссе, 4 ${ }^{2}$ Сибирский государственный университет науки и технологий имени академика М. Ф. Решетнева Российская Федерация, 660037, просп. им. газ. «Красноярский рабочий», 31

*E-mail: nazarov@sibsau.ru
} 
Неотъемлемой составляющей практически всех космических миссий являются транспортные операции, обеспечиваюшие изменение орбиты космического аппарата или перевод его на отлетную траекторию. Повышающиеся требования к эффективности транспортировки космических аппаратов формируют потребность в поиске возможных способов ее увеличения и оценке характеристик, сопутствуюших предлагаемым способам.

Применяемые в настоящее время разгонные блоки и межорбитальные буксиры, как правило, используют маршевый двигатель на химическом топливе, хотя все чаще встречаются решения с применением электроракетного двигателя. Благодаря высокой скорости истечения рабочего тела, значительно превышающей скорость истечения продуктов горения в химическом двигателе, эффективность использования массы вещества электроракетным двигателем значительно превышает этот показатель для химического двигателя. Однако малая тяга, обеспечиваемая электроракетным двигателем, приводит к высокой длительности транспортной операции и, как следствие, к значительному времени воздействия факторов космического пространства, в частности, радиачионного излучения, поэтому применение только электроракетного двигателя не всегда удовлетворяет требованиям к миссии.

Одним из перспективных направлений повышения эффективности транспортных операций является комбинирование в составе двигательной установки традиционного химического и электроракетного двигателей. Различные аспекты применения подобной комбинированной двигательной установки, состоящей из солнечной электроракетной установки и разгонного блока «Фрегат», рассматривались, например, в рамках НИР «Двина ТМ».

В отличие от химического двигателя, в котором энергия высвобождается из химических связей, энергия для ускорения рабочего тела электроракетным двигателем подводится извне. Наибольшее распространение в качестве источника энергии на околоземных орбитах, где величина солнечного излучения достаточна для удовлетворения потребностей космического аппарата в энергии, получили солнечные батареи. Солнечные батареи чувствительны к радиации, в их внутренней структуре накапливаются повреждения и их характеристики деградируют, поэтому существует потребность в учете накопленной за время выполнения транспортной операции радиаџионной дозы и оценке снижения эффективности солнечных элементов. Неравномерная интенсивность облучения в сформированных магнитным полем Земли радиационных поясах (пояса Ван Аллена) может быть учтена, если проводить оценку интенсивности радиации в точках траектории выполнения маневра с использованием модели радиачионных поясов Земли.

В работе предлагается метод, позволяюший учесть воздействие ионизирующего излучения на деградацию солнечных батарей при выполнении транспортной операџии с использованием комбинированной двигательной установки на основе ЖРД и ЭРДУ с учетом выбранной траектории и модели радиационного пояса Земли.

Ключевые слова: комбинированная двигательная установка, электроракетный двигатель, радиационный пояс Земли, солнечная батарея, деградация.

Introduction. Transport operations that ensure the change of the orbit of a spacecraft or its transfer to the departure trajectory are an integral part of almost all space missions. Increasing requirements for the efficiency of transporting spacecraft form the need to search for possible ways to increase this efficiency and assess the characteristics associated with the proposed methods. Current boosters and interorbital tugs, as a rule, use a chemically powered cruise engine, although solutions with the use of an electric jet engine are becoming more common [1]. Due to the high rate of the outflow of working fluid which is much higher than that of combustion products in a chemical engine, the efficiency of use of the substance mass by an electric jet engine significantly exceeds this indicator for a chemical engine [2]. However, the low thrust provided by the electric jet engine leads to high duration of the transport operation and, as a result, to considerable time of exposure to the outer space factors, in particular, radiation [3-5]. Therefore, the use of the electric jet engine only does not always meet the requirements for the mission.

One of the promising ways to increase the efficiency of transport operations aimed at changing the orbit of a spacecraft or transferring it to departure trajectories is the use of an electric jet engine as a part of a booster with a traditional chemical propulsion system [6]. It is assumed that this combination of engines of different types allows using a particular engine in different phases of the transport operation, increasing its overall efficiency. Various aspects of the use of such an integrated propulsion system consisting of a solar electric jet system and "Fregat" booster was considered in the framework of "Dvina TM" research project [7].

Unlike a chemical engine, in which energy is released from chemical bonds, the energy for accelerating the working fluid by an electric jet engine is supplied from outside. Solar batteries (SBs) based on semiconductor photocells are the most widespread energy source in nearearth orbits, where the amount of solar radiation is sufficient to meet the energy needs of a spacecraft. SBs are subject to degradation under the influence of high-energy charged particles [8-10]. Uneven irradiation intensity in radiation belts formed by the Earth's magnetic field (Van Allen belts) $[11 ; 12]$ suggests that accounting for the intensity of radiation exposure should be carried out along the trajectory of the maneuver and taking into account the model of the Earth's radiation belts.

To assess the impact of heavy ions (HIs) on the degree of degradation of the SBs, design programs have been established in Russia and abroad. For example, in Russia, the Research Institute of Applied Mechanics and Electrodynamics (RIAME) of Moscow Aviation Institute (MAI) created BUKSIR program [13], which allows estimating by calculation the degree of degradation of any of the 
30 types of solar batteries depending on the spacecraft flight altitude, orbit inclination and time spent in this orbit.

European Space Agency (ESA) has developed SPENVIS (Space Environment Information System) program [14], which allows estimating radiation doses accumulated by spacecraft and their elements during the flight, depending on the specified orbits and time spent on them. The program also made it possible to predict a decrease in the efficiency of SBs during their active existence depending on the types of SB cells, types and thickness of protective coatings, and to take into account the obtained data when designing both the spacecraft themselves and their electric power supply (EPS) systems and developing ballistic maneuvers extending the active lifetime (ALT) of spacecraft (SC).

Existing software for evaluating the effects of radiation on spacecraft, such as SHIELDOS, SPENVIS, STK SEET, allows calculating the integral dose accumulated by the SB, assessing the degradation of photocells depending on their type and thickness of the protective coating. However, this software does not satisfy the needs of studying the characteristics of degradation of solar cells when performing active maneuvers using high and low thrust engines according to a specific cyclogram, which occurs when performing a transport operation using an integrated propulsion system. Therefore, basic methods and algorithms published in the public domain were used to conduct the study and a method that allows solving the problem in the desired formulation was proposed on their basis.

Considerable flight duration on low thrust engines requires substantial computational powers to perform numerical integration of differential equations used for the mathematical description of various phases of the general maneuver. The need for practical implementation of the numerical experiment required the simplification of the models in use, the optimization of the algorithms and computational methods in use, as well as the application of computers with high computational capabilities.

Motion Model. The transport operation of the coplanar transition between circular orbits (from low to high) was investigated. In general, the problem of estimating the effect of the composition of an integrated propulsion system on the integral dose of radiation when orbiting a spacecraft was considered by the authors earlier in [15] In addition to the methodological interest in terms of developing a method for assessing the degradation of solar panels and the effect of the composition of the integrated propulsion system on it, such an operation may be of practical interest, since there are promising projects for placing into geosynchronous orbits for which the transport operation has a high similarity with the idealized one [16].

The flight maneuver between coplanar circular orbits (from a smaller to a bigger one) consists of 2 phases (fig. 1):

1. Gomanovsky flight using high-thrust engines;

2. Retrieval of the spacecraft to the target highelliptical orbit along a spiral trajectory by low-thrust engines.
The optimality of a two-pulse flight along a semielliptical trajectory in the chemical phase is shown in [17]. The flight between circular coplanar orbits with the help of a low-thrust engine is considered in [18].

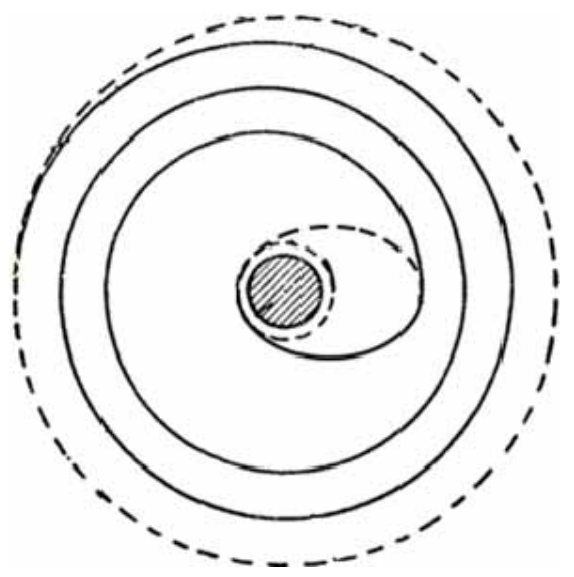

Fig. 1. Flight trajectory of artificial earth satellite (AES) from low earth orbit (LEO) to geostationary earth orbit (GSO) using integrated propulsion system (IPS)

Рис. 1. Траектория перелета искусственного спутника Земли (ИСЗ) с низкой околоземной орбиты (НОО) на геостационарную околоземную орбиту (ГСО) с использованием комбинированной двигательной установки (КДУ)

Knowing the initial mass of the SC, the parameters of the used propulsion engines (PE) that are parts of the IPS (thrust, specific impulse), the parameters of the initial and final orbits, one can enter a parameter $k \in(0 \div 1)$ that determines the position of the intermediate circular orbit to which the $\mathrm{SC}$ is placed using the high-thrust engine along Gomanovsky transition orbit.

$$
R_{2}=R_{1}+k\left(R_{3}-R_{1}\right),
$$

where $R_{1}$ is the radius of the LEO, $R_{3}$ is the radius of the GSO.

The parameter $k$ uniquely specifies the radius of the intermediate orbit $R_{2}$. A cyclogram of engine operation can be constructed on the basis of analytical dependencies.

The first phase of the maneuver is performed according to Gomanovsky two-pulse flight. On the basis of ballistic calculations, for a given ratio of orbits $\bar{r}=\frac{r_{2}}{r_{1}}$ the necessary increments for the first and second pulses are the following:

$$
\begin{gathered}
\Delta V_{1}=V_{1}\left(\sqrt{\frac{2 \bar{r}}{\bar{r}+1}}-1\right), \\
\Delta V_{2}=V_{1} \frac{1}{\sqrt{\bar{r}}}\left(1-\sqrt{\frac{2}{\bar{r}+1}}\right),
\end{gathered}
$$

where $V_{1}$ is the velocity of the $\mathrm{SC}$ in the initial circular orbit: 


$$
V_{1}=\sqrt{\frac{\mu_{E}}{r_{1}}}
$$

where $\mu_{E}$ is the gravitational parameter of the Earth.

The required expenses of the working fluid will be:

$$
\Delta m=M\left(1-\exp \left(-\frac{\Delta V}{I_{S P}}\right)\right),
$$

where $M$ is the mass of the apparatus before issuing the corresponding impulse; $I_{S P}$ is the specific impulse realized by the CE (chemical engine).

Pulse durations will be:

$$
\Delta t=I_{S P} \frac{\Delta m}{R},
$$

where $R$ is the thrust of CE.

Moments of impulses:

$$
\begin{gathered}
t_{0}=0, \\
t_{1}=\pi \sqrt{\frac{a^{3}}{\mu_{E}},}
\end{gathered}
$$

where $a$ is the semi-major axis of the transition ellipse.

As a result of the first phase, the SC is transferred to a circular orbit with the radius $r_{2}$. The second phase of the transport operation begins with the firing of an electric jet engine and a long transition along a spiral trajectory. Engine thrust during the entire time the maneuver is executed coincides with the velocity vector. The calculations are done according to the formulas proposed in [5]

$$
\Delta t=\frac{M}{\dot{m}}\left(1-\exp \left(\frac{\sqrt{\mu_{E}}}{I_{S P}}\left(\frac{1}{\sqrt{r_{3}}}-\frac{1}{\sqrt{r_{2}}}\right)\right)\right),
$$

gives an approximation sufficient for the problems to be solved.

The result of the second phase of the transport operation is the transition to the target circular orbit.

Radiation field model. Depending on the SC parameters, the initial and final orbits and the parameter $k$, the $\mathrm{SC}$ will move along different trajectories passing through areas of space with different levels of ionizing radiation from outer space (IROS).

Ionizing radiation includes the following types of radiation [9; 19-23]:

- radiation from the natural radiation belts of the Earth (NRBE) (protons, electrons, $\alpha$-particles, nuclei);

- solar cosmic rays (SCR) (protons, electrons, $\alpha$-particles);

- solar wind (protons, electrons, $\alpha$-particles);

- galactic cosmic rays (GCR) (protons, electrons, $\alpha$-particles, nuclei);

- particles in the external magnetosphere (protons, electrons, $\alpha$ particles), albedo particles (protons, neutrons), UDS-radiation from unclosed drift shells (protons, electrons), particles precipitating during magnetic disturbances (protons, electrons) and others.
Galactic cosmic radiation is characterized by small fluxes (up to 5 particles $\times \mathrm{cm}^{-2} \times \mathrm{s}^{-1}$ ) and high particle energies (up to $10^{20} \mathrm{eV}$ ).

The primary cosmic rays of galactic origin can be attributed to sources of NRBE particles (high-energy protons resulting from the decay of albedo neutrons formed by GCR particles interacting with atmospheric nuclei).

SCRs are formed during chromospheric solar flares. Large fluxes of high-energy SCR particles can pose a radiation hazard to semiconductor radio-electronic products (REP), which are a part of the SC instrument cluster. The total dose of radiation received by a spacecraft throughout the maneuver can be obtained by integration of individual doses obtained while the spacecraft is at a particular point in space, the level of IR (ionizing radiation) in which is known.

A dipole is adopted as a model of the Earth's magnetic field, whose axis is shifted relative to the geographic axis by 11.4 degrees [20; 24-26]. It is known that the intensity of charged particles fluxes has a high spatial gradient. A change in distance by $3 \%$ creates a change in the flux intensity by 10 times at small heights in the inner zone. Therefore, it is not possible to use the dipole model in Cartesian or polar coordinates to determine the intensity of charged particles fluxes. One must use a coordinate system suitable for this task.

The most commonly used coordinate system is that of McIlwain [27-29], in which the fluxes of charged particles with equal intensity are placed on surfaces that can be described in $L-B$ coordinates. A spatial distribution of intensities which formed the basis of the AP8 and AE8 models for protons and electrons, respectively [30] was obtained on the basis of experimental data collected during launches of the satellite for studying the Earth's magnetosphere.

Since solar cells cannot be protected by a layer of considerable thickness, it is necessary to use the values of both protons and electrons of the entire energy spectrum for the purpose of studying the effect of HIs on their degradation. Fluence is conveniently accumulated in the energy zones described in documents AP8 and AE8. Integral fluence accumulated during the entire transport operation can be obtained by integrating with preservation of the division of the influencing flows into energy zones (separately for protons and electrons):

$$
D(E)=\int_{T} P(\vec{r}, E) d t,
$$

where $D$ is the accumulated fluence for HIs with energy in the range of $\mathrm{E}$ zone; $P(\vec{r}, E)$ is the intensity of radiation at the point of space $\vec{r}=[x y z]^{T}$ for HI with energy in $E$ zone.

The model of solar cells degradation. Solar cells are the most common source of energy for SC. Solar cells based on monocrystalline silicon are the most common ones, their production technology is well developed, and the efficiency of modern elements is high. Elements based on gallium arsenide are less common; they have a number of advantages and greater efficiency, but their production is relatively poorly developed, and the cost is noticeably higher than that of silicon ones. 


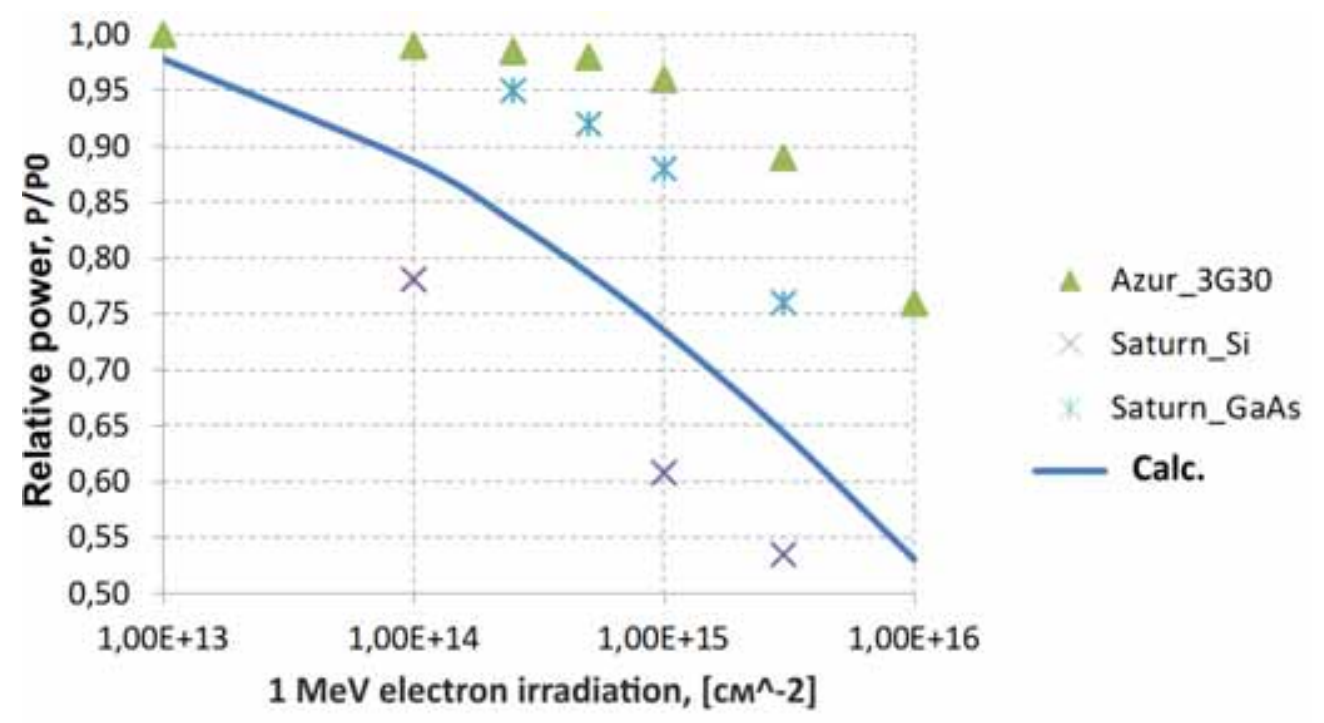

Fig. 2. Degradation of solar cells power depending on the integral fluence of $1 \mathrm{MeV}$ monoenergetic electrons

Рис. 2. Деградация мощности солнечных фотоэлементов в зависимости от интегрального флюенса моноэнергетических электронов 1 МэВ

Solar cells operating in space conditions undergo the effect of gradual degradation of their characteristics under the influence of defects accumulation due to the influence of HIs [31]. Several mechanisms of the influence of HIs on the solar cells structure are known and theoretically described [9].

There are a number of techniques $[8 ; 32 ; 33]$ for estimation of the degradation of solar cells characteristics under the influence of radiation exposure. JPL method was used for the purpose of the conducted research. According to this method the effect of mono-energetic electron flux with energy of $1 \mathrm{MeV}$ on solar cells without protective coating is experimentally evaluated. Measurements are carried out on installations with an appropriate energy source and a measurement system that records changes in the characteristics of solar cells. The dependence of the characteristics (short circuit current, no-load voltage, maximum power) on the total effect of the radiation flux is constructed on the basis of the experimental data obtained. On the basis of theoretical models of degradation and their subsequent verification by experiments, it is generally accepted that the effects of other HIs can be reduced to the effects of electrons with the energy of $1 \mathrm{MeV}$. Thus, it becomes possible to determine the net effect from different types of HIs (electrons and protons) of a wide energy spectrum taking into account various protective coatings.

The formula proposed in [13] which describes the decrease in power from the integral fluence

$$
\frac{N}{N_{0}}=1+0.0241 \cdot \log \left(\frac{D_{\Sigma}}{10^{12}}\right)-0.0466 \cdot\left[\log \left(\frac{D_{\Sigma}}{10^{12}}\right)\right]^{1.8},
$$

agrees well with the experimental data on solar cells provided by manufacturers [34-36] (fig. 2).

Integral fluences accumulated during the transport operation in various energy spectra can be converted into an equivalent monoenergetic fluence of electrons with energy of $1 \mathrm{MeV}$ for a given type of protective coating according to the formula (12) published in [8]:

$$
\begin{gathered}
\Phi_{1 \text { MeVelectron }}=\int \frac{d \Phi_{E}\left(E_{E}\right)}{d E_{E}} \cdot R D C\left(E_{E}, t\right) d E_{E}+ \\
+C_{P E} \int \frac{d \Phi_{P}\left(E_{P}\right)}{d E_{P}} \cdot R D C\left(E_{P}, t\right) d E_{P},
\end{gathered}
$$

where $\frac{d \Phi_{E}\left(E_{E}\right)}{d E_{E}}, \frac{d \Phi_{P}\left(E_{P}\right)}{d E_{P}}$ is fluence density of electrons and protons on the energy spectrum, $\operatorname{RDC}\left(E_{E}, t\right), \operatorname{RDC}\left(E_{P}, t\right)$ is the function of equivalent damage from the action of HIs with energy $E$ with a protective coating of thickness $t, C_{P E}$ is the experimental coefficient of conversion of proton fluence into electron fluence.

Algorithm and simulation. The data obtained during the ballistic planning of a transport operation form a sequence diagram of a transport operation. This approach allows solving the following tasks:

- to check the correctness of the ballistic planning;

- to get the fluence values at the point of space where the SC is currently located and to determine the integral dose of exposure.

The dynamics of SC flight is simulated in the geocentric inertial coordinate system. To reduce computational complexity, it is considered that the starting point of the maneuver coincides with the axis of the inertial GCS (geocentric coordinate system). The axis of the magnetic dipole rotates with the rotation of the Earth. To calculate the level of IR (ionizing radiation) at the current point in space, the coordinates of the inertial GCS are converted into dipole coordinates, after which the IR values are calculated in accordance with AP8 model. 
A mathematical model was constructed to study the effect of phase distribution for IPS engines on the integral dose obtained by the SC during the time of the maneuver. The model solves the following main tasks:

- flight planning.

- iterative modeling;

- estimation of the radiation intensity of electrons and protons of different energy spectrum.

The algorithm of numerical calculations corresponding to the proposed model is shown in fig. 3 and consists of a series of sequential operations:

1. The SC parameters and the IPS engines parameters are set.

2. The initial and final orbits, the distribution of the trajectory maneuver between phases 1 and 2 are set.

3 . The initial state vector (position, speed, acceleration) is set.

4. The scheduler performs calculations according to the specified parameters and draws a sequence diagram for starting the engines.

5. The solver performs the sequence diagram step by step, determining the coordinates of the SC at the next step, calculates and sums up the value of the particle flux at a given point in space.

6 . The output unit forms a flight trajectory and an output data set corresponding to a given input data set.

Simulation results. Final characteristics and flight trajectories were obtained for different phase relations. An example of the resulting trajectory is shown in fig. 4.

The effect of the parameter $k$ determining the ratio of the fraction of the total maneuver per part of the transport operation performed by the booster to the integral dose of radiation obtained by the $\mathrm{SC}$ during the execution of the maneuver was studied during the simulation. The parameter $k$ varied in the range of $0 \div 1$ with a step of 0.1 .

The following parameters and initial conditions were adopted for the research:

- the transport operation consists in the transition between circular coplanar orbits. The initial orbit (LEO) is $200 \mathrm{~km}$ high in the equatorial plane, the final orbit (GSO) is $35786 \mathrm{~km}$ high;

- the initial mass of the entire system is $3000 \mathrm{~kg}$;

$-\mathrm{CE}$ : thrust is $20000 \mathrm{~N}$, specific impulse is $330 \mathrm{~s}$;

- EJE: thrust is $0,2 \mathrm{~N}$, specific impulse is $2000 \mathrm{~s}$.

The analytical formulas used for planning the cyclogram of a transport operation are verified by the method of numerical integration using a physicomathematical model. Deviations of the radius of the final orbit from the specified one obtained by numerical integration based on an analytically planned cyclogram are reflected in fig. 5

The flow of HIs is calculated by energy zones for each point of the trajectory. Fig. 6 shows the calculated equivalent fluence of a monoenergy flux of electrons with the energy of $1 \mathrm{MeV}$.

Calculations of residual efficiency carried out by formula (11) for different $k$ (fig. 7) show that transport operations with $k<0.3$ have a significant effect on the degradation.

Due to the variable integration step, the number of calculated points of the trajectory for the most complicated case did not exceed 800 thousand (fig. 8).

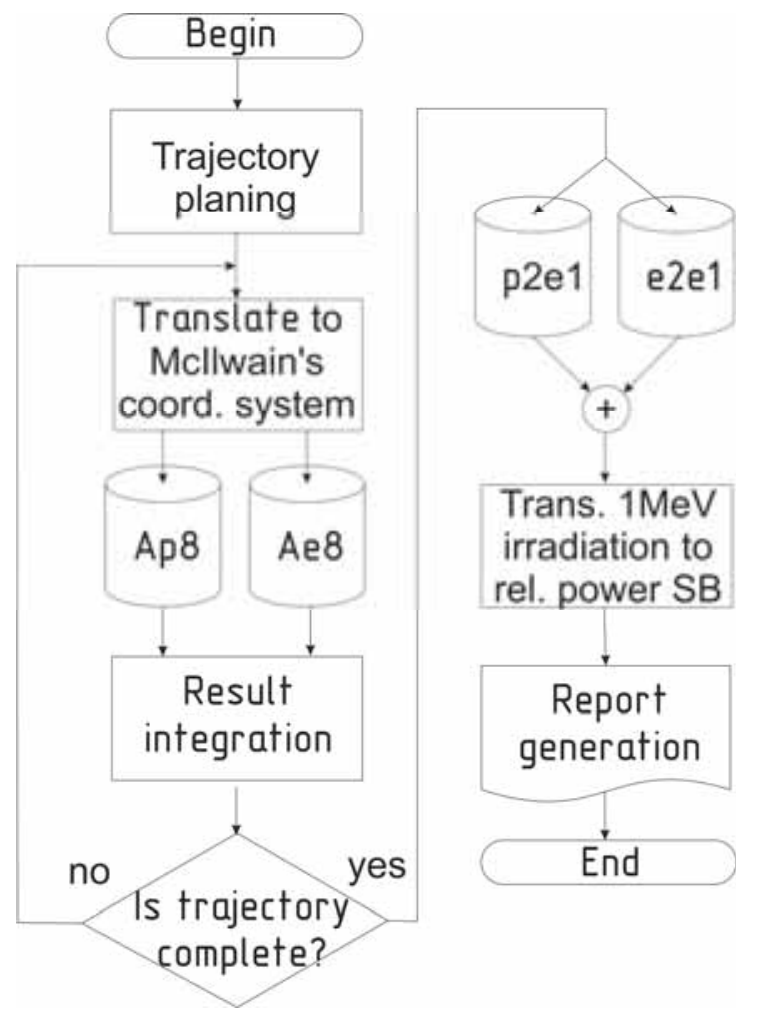

Fig. 3. Simulation flowchart

Рис. 3. Блок-схема алгоритма моделирования 


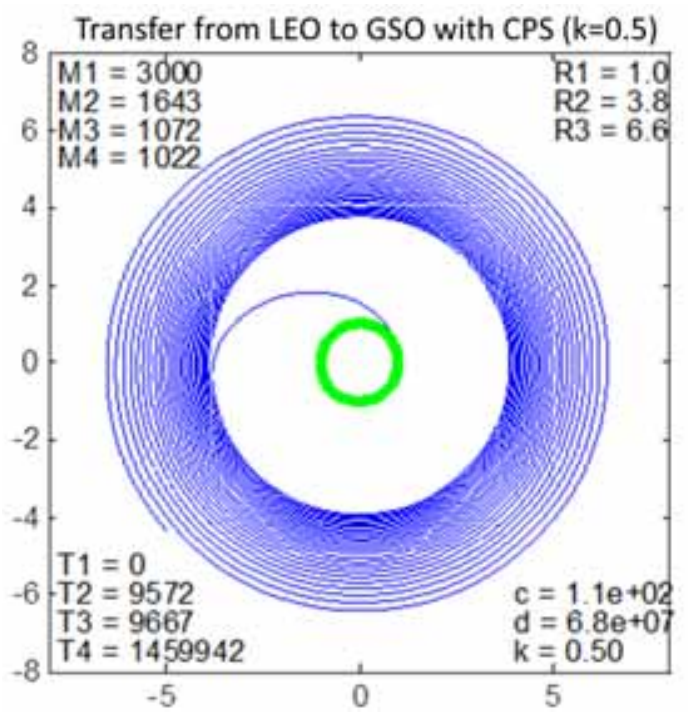

Fig. 4. Trajectory example

Рис. 4. Пример траектории

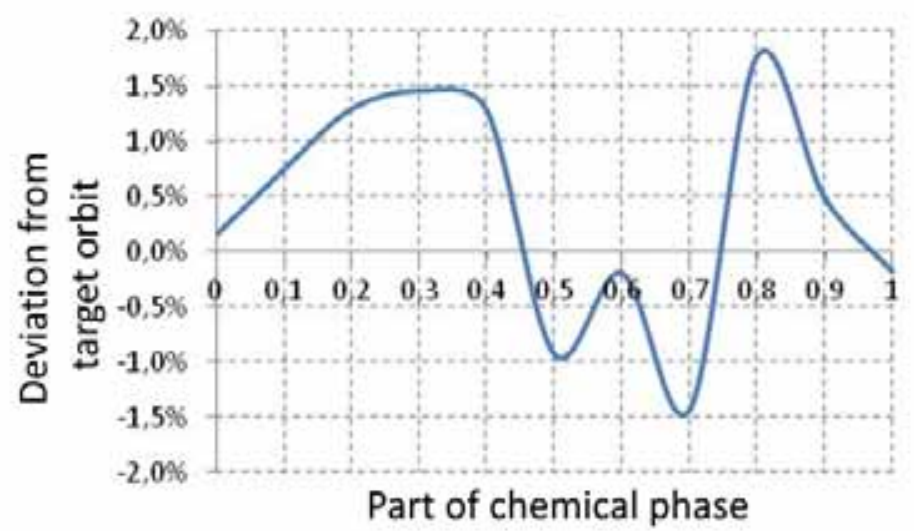

Fig. 5. Deviations of the radius of the final orbit from the specified one

Рис. 5. Отклонения радиуса конечной орбиты от заданного

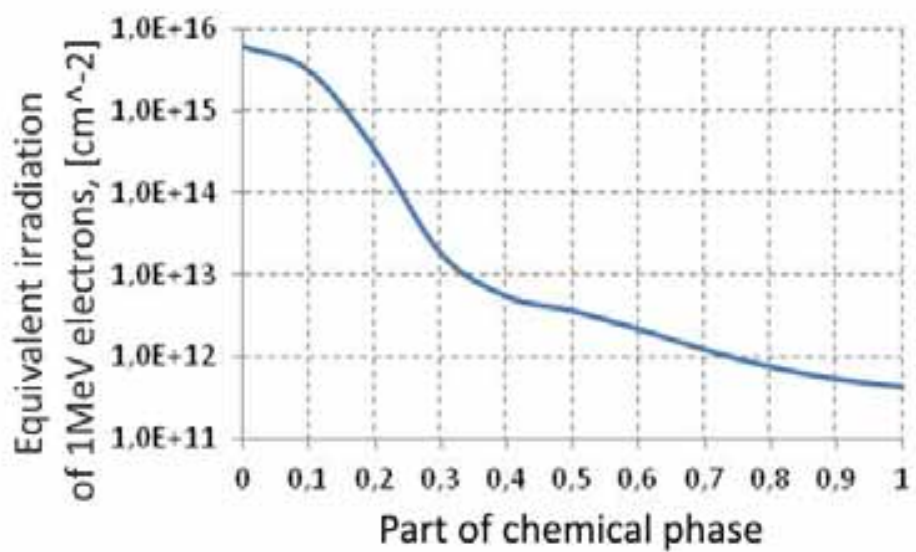

Fig. 6. Fluence of an equivalent flux of $1 \mathrm{MeV}$ monoenergetic electrons

Рис. 6. Флюенс эквивалентного потока моноэнергетических электронов 1МэВ 
In previous calculations performed with a fixed integration step the number of calculation points exceeded 10 million, which made the calculation of the equivalent fluence impracticable within a reasonable time frame.

The specified accuracy of integration was selected taking into account the balance between the required compu- tational power and the deviations of the calculations over the entire range of the coefficient $\mathrm{k}$. The computational complexity illustrated by the time of calculation depending on the parameter $k$ (fig. 9) is significant even at the current level of computational tools and required special measures to obtain results in a finite time.

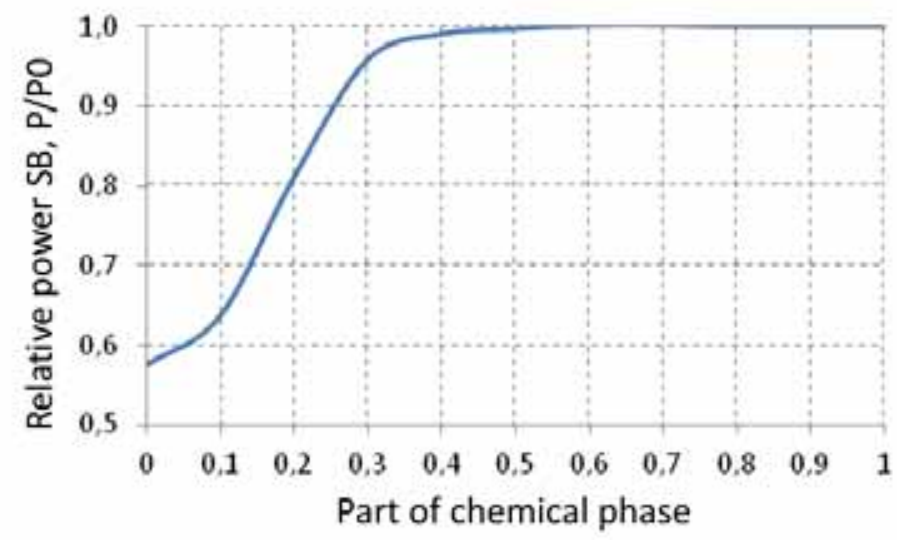

Fig. 7. Residual efficiency of SBs

Рис. 7. Остаточный КПД СБ

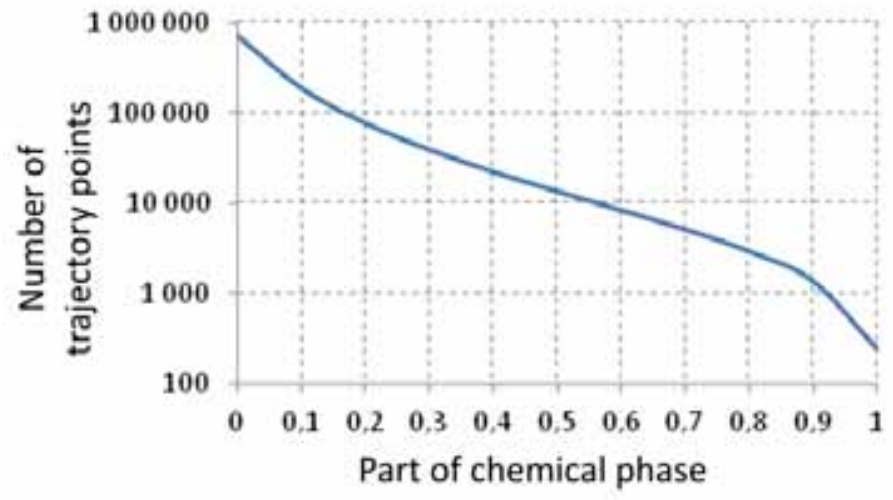

Fig. 8. The number of points of the trajectory

Рис. 8. Количество точек траектории

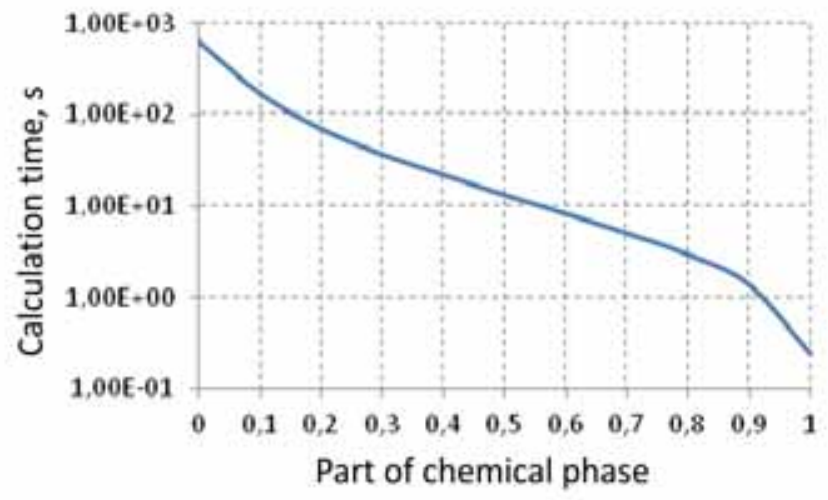

Fig. 9. Required calculation time depending on the parameter $k$

Рис. 9. Требуемое время расчета в зависимости от параметра $k$ 


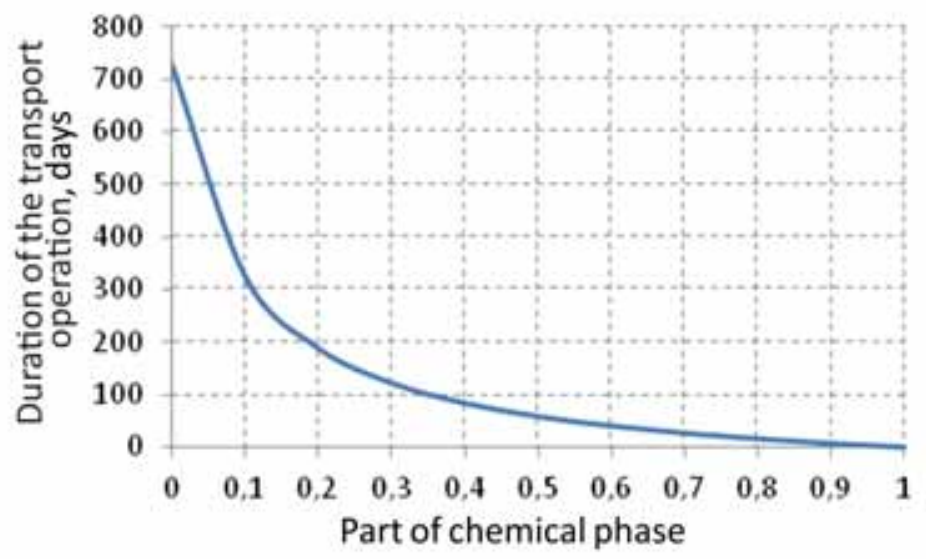

Fig. 10. Duration of the transport operation

Рис. 10. Длительность транспортной операции

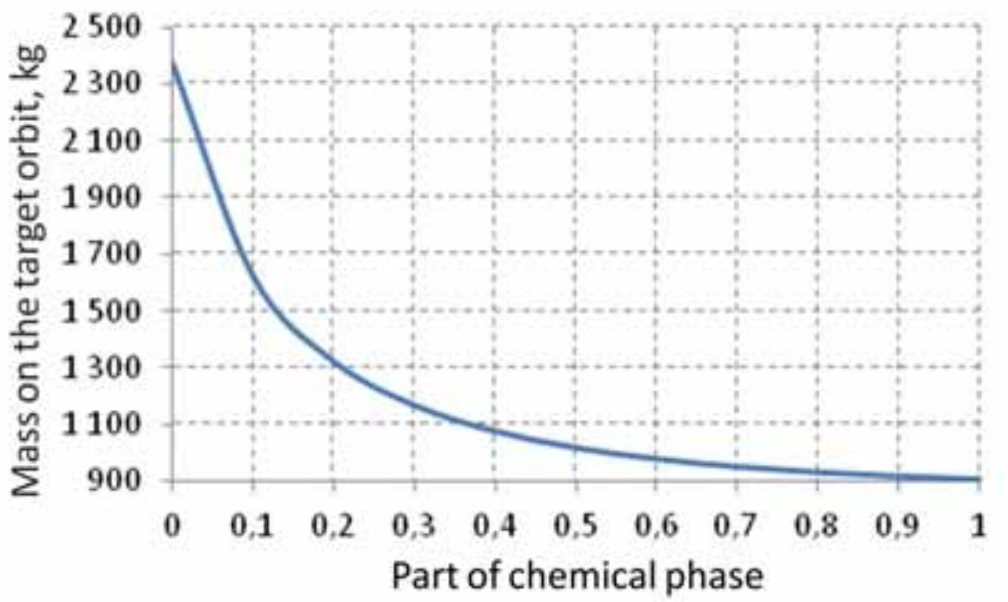

Fig. 11. Mass on the final orbit

Рис. 11. Масса на конечной орбите

The duration of the transport operation depending on the parameter $\mathrm{k}$ is displayed in fig. 10 .

The mass dependence in the final orbit is shown in fig. 11. It can be seen that the use of EJE in the booster allows placing a large mass into the final orbit.

Conclusion. The influence of the choice of the ratio between the parts of the performed maneuver between different types of engines of the integrated propulsion system of the booster is considered. A method is proposed by which the influence of ionizing radiation in near-Earth space on the degradation of the characteristics of a SC solar battery has been evaluated. It is shown that the use of a low thrust engine throughout the transport operation leads to a significant amount of accumulated radiation dose and, as a result, to decrease in the efficiency of the solar battery. Reducing the efficiency requires increasing the area of the SB and, accordingly, increasing its mass. The use of IPS consisting of high and low thrust engines allows not only flexibly controlling the flight time, varying the ratio between the phases of the transport operation performed by various types of engines, but also reducing the degradation of SB from the effects of ionizing radiation, providing a short time of SC presence in the Earth radiation belt zones due to the implementation of this phase using IPS. The developed methodology and the results obtained are an integral part of the work on a reasonable choice of the composition of the integrated propulsion system based on "Fregat" booster with an additional EJE.

\section{References}

1. [Express-AM6, the replenishment of the orbital grouping of Russia]. Sibirskiy Sputnik. 2014, Vol. 369, No. 15, P. 1-3 (In Russ.).

2. Gilzin K. A. Elektricheskie mezhplanetnye korabli [Electric Interplanetary Ships]. Moscow, Nauka Publ., 1970, $267 \mathrm{p}$.

3. The Radiation Design Handbook. European Space Agency. ESTEC, Noordwijk, the Nederland, 1993, 444 p. 
4. Birukov V. I., Birukova M. V. [Algorithm for predicting the radiation impact on the microsatellite equipment]. Vestnik Moskovskogo aviatsionnogo instituta. 2013, Vol. 20, No. 3, P. 40-49 (In Russ.).

5. Getselev I. V., Zubarev A. I., Pudovkin O. L. [Radiation situation on board spacecraft]. Strategic Missile Forces, TsIPK. 2001, No. 77, 316 p.

6. Belik A. A., Egorov Yu. G., Kulkov V. M. et al. [Analysis of the design and ballistic characteristics of a combined circuit for launching a spacecraft into a geostationary orbit using medium-class launch vehicles]. Aerokosmicheskaya Tekhnika i Tekhnologiya. 2011, Vol. 81, No. 4, P. 17-21 (In Russ.).

7. Technical task for an integral part of the development work "Creating a unified transport module based on a solar electric propulsion system for launch vehicles of medium and heavy classes". "Development of a flight demonstrator of a unified transport module based on a solar electric propulsion system". Code: OCD "DvinaTM". 2017. 18 p.

8. Messenger S. R. Space Solar Cell radiation damage modeling. US Naval Research Laboratory, Washington D. C. 2016.48 p.

9. Tapero K. I., Ulimov V. N., Chelnov A. M. $R a-$ diatsionnye Effekty $v$ Kremnievykh Integral'nykh Skhemakh Kosmicheskogo Primeneniya [Radiation effects in silicon integrated circuits for space applications]. Moscow, BINOM, Laboratoriya znaniy Publ., 2012, 226 p.

10. Fahrenbruch A. L., Bube R. H. Solnechnye Elementy: Teoriya $i$ Eksperiment [Solar Elements: Theory and Experiment]. Moscow, Energoautomizdat Publ., 1987, $247 \mathrm{p}$.

11. Van Allen J. A., Ludwig G. H., Ray E. C., McIlwain C. E. Observation of High Intensity Radiation by Satellites 1958 Alpha and Gamma. Jet Propulsion. 1958, No. 28, P. 588-592.

12. Murzin S. V. Vvedenie v fiziku kosmicheskikh luchey [Introduction to the physics of cosmic rays]. Moscow, Atomizdat Publ., 1979, 197 p.

13. Vasiliev Yu. B. [Radiation degradation of solar cells working in space]. Aerokosmicheskaya Tekhnika $i$ Tekhnologiya. 2007, Vol. 43, No. 7, P. 116 (In Russ.).

14. SPENVIS - Space ENVironment Information System, ESA. Available at: https://www.spenvis.oma.be/ (accessed: 09.07.2016).

15. Razrabotka evropeyskoy global'noy navigatsionnoy sputnikovoy sistemy Galileo [The development of the European global navigation satellite system Galileo]. TsNIIMASH Newsletter, $2 \mathrm{p}$.

16. Birukov V. I., Nazarov V. P., Kurguzov A. V. [Influence of the energy characteristics of a combined propulsion system on the integral dose of radiation when a spacecraft is placed in a geostationary orbit]. Siberian Journal of Science and Technology. 2018, Vol. 19, No. 1, P. 50-58 (In Russ.).

17. Okhotsimsky D. E., Sikharulidze Yu. G. Osnovy mekhaniki kosmicheskogo poleta [Basics of Space Flight Mechanics]. Moscow, Nauka Publ., 1990, 321 p.

18. Grishin S. D., Leskov L. V. Elektricheskie raketnye dvigateli [Electric Spacecraft Rocket Engines]. Moscow, Mashinostroenie Publ., 1989, 317 p.
19. GOST 25645.211-85. Bezopasnost' radiatsionnaya ekipazha kosmicheskogo apparata v kosmicheskom polete. Kharakteristiki yadernogo vzaimodeystviya protonov [State Standard 25645.211-85. Safety of the radiation crew of the spacecraft in space flight. Characteristics of the nuclear interaction of protons]. Moscow, Standartinform Publ., 1986. 14 p.

20. Galper A. M. Earth's Radiation Belt. Soros Educational Journal. 1999, No. 6, P. 75-81.

21. Kozlov A. A., Chumakov I. R. [Algorithm for evaluating the structural protection of spacecraft]. Radiatsionnaya stoykost' elektronnykh system. 'Stoykost'2004". Nauchno-tekhnicheskiy sbornik. 2004, Iss. 7, P. 21-22 (In Russ.).

22. Space Model, t. 2. The impact of the space environment on the materials and equipment of space vehicles. Moscow, MSU SINP, 2007, P. 317.

23. GOST RV 20.57.308-98. Radiatsionnaya stoykost'. Metody rascheta [State Standart RV 20.57.308-98. Radiation resistance. Methods of calculation]. Moscow, 1995.55 p.

24. Barth J. Applying modeling space radiation environments. 1997 IEEE Nuclear and Space Radiation Effects. Short Course. Applying Computer Simulation Tools to Radiation Effects Problems. Snowmass Conference Center. Snowmass Village, Colorado. 21 July 1997, P. 354-367.

25. Runcorn S. K. The Magnetism of the Earth's Body. Handbuch der Physik XLVII "Geophysik I", Springer, 1956, P. 498-533.

26. Voronov S. A., Gal'per A. M., Kirillov-Ugrymov V. G., Koldashev S. V., Popov A. V. [The charge composition of a stream of high-energy electrons and positrons of the Earth's radiation belt]. Pis'ma $v$ ZhETF. 1986, Vol. 43, Iss. 5, P. 240-241 (In Russ.).

27. McIlwain C. E. Coordinates for Mapping the Distribution of Magnetically Trapped Particles. Jour. Geophysical Res. 1961, Vol. 66, P. 3681-3691.

28. Fox N., Burch J. L. The Van allen probes mission. Springer, 2013. 579 p.

29. McIlwain K. E. Coordinates for mapping the distribution of particles trapped by the geomagnetic field. Operation Starfish. Collection of articles. Ed. I. A. Zhulina. Moscow, Atomizdat Publ., 1964, 216 p.

30. NASA SP-3024 Models of the trapped radiation environment. Vol. I: Inner Zone, National AERONAUTICS AND SPACE ADMINISTRATION, Washington D. C., 1966, P. 178.

31. Visentine J., Kinard W., Pinkerton R. MIR Solar Array Experiment. 36th AIAA Aerospace Sciences Meeting and Exhibit. Jan. 11-14 1999, Reno, NV. P. 194-218.

32. Tada H. Y., Carter J. R., Anspaugh B. E., Downing R. G. Solar cell Radiation Handbook. JPL Publication 82-69, 1982. $216 \mathrm{p}$.

33. OST 134-1034-2003. Methods for testing and assessing the durability of on-board radio electronic equipment for space vehicles to the effects of electronic and proton emissions of electronic and proton emissions of space through dose effects.

34. Solnechnye batarei, PAO "Saturn" [Solar batteries, JSC "Saturn"] (In Russ.). Available 
at: http://saturn-kuban.ru/produktsiya/solnechnye-batarei/ (accessed: 21.09.2016).

35. Fotoelektricheskie preobrazovateli, PAO "Saturn” [Photoelectric converter, JSC “Saturn”] (In Russ.). Available at: http://saturn-kuban.ru/produktsiya/ solnechnye-atarei/fotoelektricheskie-preobrazovateli/ (accessed: 17.11.2017).

36. Guter W. Space solar cells - 3G30 and next generation radiation product. Available at: https://www.e3s-conferences.org/articles/e3sconf/pdf/ 2017/ 04/e3sconf_espc2017_03005.pdf (accessed 03.05.2017).

\section{Библиографические ссылки}

1. «Экспресс-АМ6» пополнение орбитальной группировки России // Сибирский спутник. 2014. № 15 (369). 8 c.

2. Гильзин К. А. Электрические межпланетные корабли. 2-е изд. перераб. и дополн. М. : Наука, 1970. $267 \mathrm{c}$.

3. The Radiation Design Handbook. European Space Agency. ESTEC, Noordwijk, the Nederland, 1993. 444 p.

4. Бирюков В. И., Бирюкова М. В. Алгоритм прогнозирования радиационного воздействия на аппаратуру микроспутника // Вестник Московского авиационного института. 2013. Т. 20, № 3. С. 40-49.

5. Гецелев И. В., Зубарев А. И., Пудовкин О. Л. Радиационная обстановка на борту космических аппаратов // РВСН. 2001. № 77. 316 с.

6. Анализ проектно-баллистических характеристик комбинированной схемы выведения космического аппарата на геостационарную орбиту с использованием ракет-носителей среднего класса / А. А. Белик, Ю. Г. Егоров, В. М. Кульков [и др.]. // Авиационно-космическая техника и технология. 2011. № 4 (81). C. $17-21$.

7. Техническое задание на составную часть опытно-конструкторской работы «Создание унифицированного транспортного модуля на основе солнечной электроракетной двигательной установки для ракетносителей среднего и тяжелого классов». «Разработка летного демонстратора унифицированного транспортного модуля на основе солнечной электроракетной двигательной установки». Шифр: ОКР «ДвинаTM». 2017. $18 \mathrm{c}$.

8. Messenger S. R. Space Solar Cell radiation damage modeling. US Naval Research Laboratory, Washington D. C. 2016.48 p.

9. Таперо К. И., Улимов В. Н., Членов А. М. Радиационные эффекты в кремниевых интегральных схемах космического применения. М. : БИНОМ. Лаборатория знаний, 2012. 226 с.

10. Фаренбрух А. Л., Бьюб Р. Х. Солнечные элементы: теория и эксперимент / под ред. М. М. Колтуна. М. : Энергоатомиздат, 1987. 247 с.

11. Van Allen J. A., Ludwig G. H., Ray E. C., McIlwain, C. E. Observation of High Intensity Radiation by Satellites 1958 Alpha and Gamma // Jet Propulsion. 1958. № 28. P. 588-592.

12. Мурзин С. В. Введение в физику космических лучей. М. : Атомиздат, 1979. 197 с.
13. Васильев Ю. Б. Радиационная деградация солнечных батарей при работе в космосе // Авиационно-космическая техника и технология. 2007. № 7 (43). 116 c.

14. SPENVIS - SPace ENVironment Information System, ESA [Электронный pecypc]. URL: https:/www.spenvis.oma.be/ (дата обращения: 20.11.2018).

15. Развитие европейской глобальной навигационной спутниковой системы Галилео // ЦНИИМАШ, Информационный бюллетень. 2 с.

16. Бирюков В. И., Назаров В. П., Кургузов А. В. Влияние энергетических характеристик комбинированной двигательной установки на интегральную дозу радиации при выводе космического аппарата на геостационарную орбиту // Сибирский журнал науки и технологий. 2018. Т. 19, № 1. С. 50-58.

17. Охоцимский Д. Е., Сихарулидзе Ю. Г. Основы механики космического полета. М. : Наука, 1990. $321 \mathrm{c}$.

18. Гришин С. Д., Лесков Л. В. Электрические ракетные двигатели космических аппаратов. М. : Машиностроение, 1989.317 с.

19. ГОСТ 25645.211-85. Безопасность радиационная экипажа космического аппарата в космическом полете. Характеристики ядерного взаимодействия протонов. М. : Стандартинформ, 1986. 14 р.

20. Гальпер, А. М. Радиационный пояс Земли // Соросовский образовательный журнал, 1999. № 6. C. $75-81$.

21. Козлов А. А., Чумаков А. И. Алгоритм оценки конструкционной защиты космических аппаратов // Радиационная стойкость электронных систем «Стойкость-2004» : науч.-техн. сб. 2004. Вып. 7. C. 21-22.

22. Воздействие космической среды на материалы и оборудование космических аппаратов // Модель космоса. 2007. Т. 2. 308 с.

23. ГОСТ РВ 20.57.308-98. Радиационная стойкость. Методы расчета. М., 1995. 55 с.

24. Barth J. Applying modeling space radiation environments // 1997 IEEE Nuclear and Space Radiation Effects. Short Course. Applying Computer Simulation Tools to Radiation Effects Problems. Snowmass Conference Center. Snowmass Village, Colorado. 21 July 1997. P. 354-867.

25. Runcorn S. K. The Magnetism of the Earth's Body. Handbuch der Physik XLVII "Geophysik I", Springer, 1956, Р. 498-533.

26. Зарядовый состав потока высокоэнергичных электронов и позитронов радиационного пояса Земли / С. А. Воронов, А. М. Гальпер, В. Г. КирилловУгрюмов [и др.] // Письма в ЖЭТФ. 1986. Т. 43, № 5. С. 240-241.

27. McIlwain C. E. Coordinates for Mapping the Distribution of Magnetically Trapped Particles // Jour. Geophysical Res. 1961. № 66. P. 3681-3691.

28. Fox N., Burch J. L. The Van allen probes mission. Springer, 2013. 579 p.

29. Мак Илуэйн К. Е. Координаты для отображения распределения частиц, захваченным геомагнит- 
ныи полем // Операция Морская звезда : сб. статей / под ред. И. А. Жулина. М. : Атомиздат, 1964. 261 с.

30. NASA SP-3024 Models of the trapped radiation environment. Vol. I: Inner Zone, National AERONAUTICS AND SPACE ADMINISTRATION, Washington D. C., 1966, P. 178.

31. Visentine J., Kinard W., Pinkerton R. MIR Solar Array Experiment. 36th AIAA Aerospace Sciences Meeting and Exhibit. Jan. 11-14 1999, Reno, NV. P. 194-218.

32. Tada H. Y., Carter J. R., Anspaugh B. E., Downing R. G. Solar cell Radiation Handbook. JPL Publication 82-69, 1982. $216 \mathrm{p}$.

33. ОСТ 134-1034-2003. Методы испытаний и оценки стойкости бортовой радиоэлектронной аппаратуры космических аппаратов к воздействию электронных и протонных излучений космического пространства по дозовым эффектам.
34. Солнечные батареи. ОАО «Сатурн» [Электронный ресурс]. URL: http://saturn-kuban.ru/ produktsiya/solnechnye-batarei/ (дата обращения: 21.09.2016).

35. Фотоэлектрические преобразователи. OAO «Сатурн» [Электронный ресурс]. URL: http://saturn-kuban.ru/produktsiya/solnechnye-batarei/ fotoelektricheskie-preobrazovateli/ (дата обращения: 17.11.2017).

36. Guter W. Space solar cells - 3G30 and next generation radiation hard product [Электронный ресурс]. URL: https://www.e3s-conferences.org/articles/e3sconf/ pdf/2017/ 04/ e3sconf_espc2017_03005.pdf (дата обращения: 03.05.2017).

(C) Birukov V. I., Nazarov V. P, Kurguzov A. V., 2019

Biruykov Vasiliy Ivanovich - professor, Dr. Sc., Moscow Aviation Institute (National Research University). E-mail: aviatex@mail.ru.

Nazarov Vladimir Pavlovich - Cand. Sc., professor, head of Department of Aircraft Engines, Reshetnev Siberian State University of Science and Technology. E-mail: nazarov@sibsau.ru.

Kurguzov Alexey Vyacheslavovich - Postgraduate Student; Moscow Aviation Institute (National Research University). E-mail: mandigit@yandex.ru.

Бирюков Василий Иванович - доктор технических наук, профессор; Московский авиационный институт (национальный исследовательский университет). E-mail: aviatex@mail.ru.

Назаров Владимир Павлович - кандидат технических наук, профессор, заведующий кафедрой двигателей летательных аппаратов; Сибирский государственный университет науки и технологий имени академика М. Ф. Решетнева. E-mail: nazarov@sibsau.ru.

Кургузов Алексей Вячеславович - аспирант, Московский авиационный институт (национальный исследовательский университет). E-mail:mandigit@yandex.ru. 